\title{
Kidnapping and Hostage-Taking in Niger Delta Region of Nigeria: Implication for Social Work Intervention with Victims
}

\author{
Okafor, Agnes E.; Ajibo, Henry T.; Chukwu, Nma-Njoku A. \\ Department of Social work \\ University of Nigeria \\ Nsukka, Nigeria \\ Egbuche, Miriam N.; Asadu, Ngozi \\ Department of Sociology \& Anthropology \\ University of Nigeria \\ Nsukka, Nigeria
}

\begin{abstract}
There have being an alarming recurrent kidnapping and hostage-taking in Niger Delta region of Nigeria. Significant numbers of the members of the society are becoming victims of abductions; armed robbers, fraudsters and small-time crooks have engaged in the seeming lucrative venture of kidnapping. Evidently, the targets were foreign oil companies' expatriates' who were taken by oil rebels' usually on attacks in the energy-rich Niger Delta region. The criminal elements are becoming more interested in kidnapping wealthy locals. The paper examines the origin of kidnapping and hostage taking as it poses serious implication Social Work intervention in Niger Delta. This study adopted descriptive research design with systematic review of literatures. The study made use of secondary data such as newspapers, journal articles and periodicals. The study adopted social learning theory and task centered therapy (model) as the theoretical framework for the study. Finding of the study shows that there is significant psychological traumatic impact of kidnap and hostage taking on victims. The paper recommended multi agency social work practice and collaboration in effort to ameliorate the plight of kidnap victims. The paper also recommended the need for social work proactive counseling and reintegration of kidnap victims with post traumatic disorder into the mainstream of their family and the society in general.
\end{abstract}

Keywords: Kidnapping, Hostage-Taking, Social-Work, Intervention, Victims, Niger-Delta.

\section{Introduction}

There are currently at least 25,000 kidnapping for ransom cases across the world. However, most cases go unreported, so it's likely the real figure is more than 50,000 (Moorhouse, 2018).Terrorist hostage taking and kidnapping has become an international concern over the last two decades. Since the mid-1990s, hostage taking and kidnapping have dramatically increased as a preferred tactic of political terrorists and resource struggle (Yun, 2008). The kidnappers or hostage takers use kidnapping for ransom to finance their activities which constitute treat to peace, security, and development in these regions and to the right to life, liberty, and security of persons (Global Counterterrorism Forum [GCF], 2017)Until recently, kidnappings only involved one or two hostages, however, now hostage-takers are starting to go after groups as large as 25 (Moorhouse, 2018).It is widely acknowledged that victims of kidnap and hostage-taking may be individuals, family members, a community or a whole ethnic, religious, racial group or an entire nation. Their fundamental human rights are in most cases denied and inhuman treatments are meted against victims by perpetrators (United Nation [UN], 2013).

The rate of kidnapping and hostage taking in Africa has taken an alarming dimension in the last two decades. Africa countries such as Mali, Somali, Kenya, Nigeria, Egypt, Cameroun, Ethiopia and the rest of them have witnessed its citizens kidnapped for ransom and also for political victimization (Okeowo, 2013). Since the mid2000s, terrorism, kidnapping and hostage taking has pushed the peripheries of West Africa into the news and the public eye (Walther \&Retaille, 2011). For example, a study titled "Piracy off the Horn of Africa" by Ploch, Blanchard, O'Rourke, Mason and King (2011) reported several incidences of pirates in Somalia hijacking ships and kidnapping travelers for ransom collection. At least 219 attacks occurred in the region in 2010, with 49 successful hijackings. 
Nigeria was globally declared as one of the terrible nations to subsist in the world as a result of the widespread of corruption, injustice, violence and lack of security that exposed many innocent citizens to end up in the hands of kidnappers. As a result of this, Nigeria was ranked in the global index as one of the worst places to dwell in because of frequent kidnapping incident (Abdulkabir, 2017). Similarly, Kidnapping is one of Nigerian's biggest challenges, facts and figures show that the kidnapping frequency in the country is high (Uzochukwu, 2018). In Nigeria kidnapping and hostage taking has been perpetuated by criminal elements for the purpose of ransom collection. The rise of Boko Haram insurgency in 2011 also gave rise to kidnapping and hostage taking by the terrorist who believe that they are fighting the government and western education for the purpose of establishment of Islamic State of Nigeria. On the other hand, there has been a lot of incidence of kidnapping and hostage taking in the Niger Delta region by militants group such as Niger Delta Vigilante (NDV), Niger Delta People's Volunteer Force (NDPVF), Movement for the Emancipation of the Niger Delta (MEND), Niger Delta Liberation Front (NDLF), and Niger Delta Avengers (NDA).

\section{Conceptualization}

Kidnapping: It is an act of abducting and holding a person or group of people captive, typically to obtain a ransom. Sometimes kidnappers hold their captives longer in order to demand more from the relatives of the victim (Uzochukwu, 2018).

Hostage taking: Any person who seizes or detains and threatens to kill, to injure or maim or to continue to detain another person in order to compel a third party, namely, a State, an international intergovernmental organization, a natural or juridical person, or a group of persons, to do or abstain from doing any act as an explicit or implicit condition for the release of the hostage commits the offence of taking of hostages ("hostage-taking") (United Nations [UN], 2013).

Social Work Intervention: social workers offer intervention to individuals, families and groups or community, which enable them to meet their needs and issues (Boihtlung, 2017). The major purpose for social work intervention is to aid kidnap victims in alleviating problems associated with abduction and to enhance their psychosocial and entire wellbeing.

Niger Delta Region of Nigeria: Niger Delta is the delta of the Niger River sitting directly on the Gulf of Guinea on the Atlantic Ocean in Nigeria. It is considered to be located within nine coastal southern Nigerian states, which include: all six states from the South South geopolitical zone, one state (Ondo) from South West geopolitical zone and two states (Abia and Imo) from South East geopolitical zone (Hogan, 2013). The Niger Delta region accounts for over 90 per cent of Nigeria's proven gas and oil reserves; and the gas and oil sector currently earns the Federal Government more than $90 \%$ of its foreign exchange (Stakeholder Democracy Network [SDN], 2018).

\section{Theoretical Framework}

Social learning theory and task centered therapy (TCT) formed the theoretical framework for this study. Social learning theory was propounded by Albert Bandura in 1977. The basic tenet of the theory is that behavior is learned from environment through the process of observational learning (Mcleod, 2016). For example, children acquire their behavior through observing people around them; hence behavior is learned. Social learning theory also stipulates that behavior is acquired through observation and imitating others (Bandura, 1971). Similarly, David (2015) added that social learning theory indicates that behavior is learned through modeling; put in other words "following the footsteps of others".

In relation to the subject matter, social learning theory explains the rational for the persistent incidence of kidnapping and hostage taking in Nigeria and Niger delta region in particular. Kidnapping for ransom have proven to be a lucrative endeavor as a result of the large amount of money victims pay to their abductors. As a result of this, many young people have gone into kidnapping because by their observation those who go into it are making it financially, likewise them too can make it through same means; hence the persistence incidence of kidnapping.

Task centered therapy (model) was formulated by Laura Epstein and Williams Reid at the University of Chicago School of Social Service Administration (SSA). Task Centered Model is a social work technology designed to help service users and social workers collaborate on specific measurable and observable goals (Kelly, 2013). The social worker according to this model gives the client specific tasks which is geared towards solving the client problems; it is task base. 
In relation to the subject matter; the social worker in order to help kidnap victims to recover from psychological trauma collaborate with kidnap victims through issuance of specific task which will help them to recover from psychological trauma upon accomplishment of task.

\section{Methodology}

The study was conducted in Niger Delta region of Nigeria. Nigeria's oil-rich Niger Delta is situated in the south of Nigeria and centers on the natural delta of the Niger River. All of Nigeria's oil production takes place on the land or waters of the nine oil producing states consisting of the extended delta region (Francis, LaPin\&Rossiasco, 2011).The study adopted descriptive research design with systematic review of literatures. The study made use of secondary data such as newspapers, journal articles and periodicals.

\section{Historical Antecedents of kidnapping and hostage taking in Niger Delta Region of Nigeria}

Kidnapping assumed an alarming dimension in the Niger Delta region of Nigeria over several decades. Its incidence and impact were precipitated by oil resource exploration in the country (Azgaku, 2014). Similarly, political kidnapping was introduced by the Niger Delta militants, who targeted foreigners, especially Americans and the British, mainly to draw attention to their plight of environmental degradation, caused by oil and gas exploration and production. The hostages were usually kept for a week and released after ransom and political demands have been met (Amachree, 2017).

The indigenes of Niger Delta region felt that the oil proceeds were not fairly distributed and as a matter of fact, they were being cheated and marginalized when it comes to reaping the benefits of crude oil that is gotten from their father's and fore father's land. This perceived injustice made the indigenes of Niger Delta region and most of the south- southerners to take to guns. They started using violence, kidnapping and hostage taking to press down their demands to the federal government, which at the initial stage was adamant to their request. On January $11^{\text {th, }}$ 2006, what appeared to be the first reported case of abduction of expatriate took place when four foreign oil workers working for shell petroleum were kidnapped by militants in Port Harcourt.

On January $15^{\text {th }}$, 2006 ten persons including soldiers of the Military Joint Task Force sent by the Federal Government to the Niger-Delta region were killed. Again, on February, ${ }^{\text {th }}$ 2007, the militants warned all expatriates to leave Nigeria with immediate effect. Kidnapping and hostage taking by the militant group persisted. Different government administration made numerous attempts through dialogue and negotiation on how to come to cease fire by the militant group, but the effort did not yield result. Kidnapping and hostage by the militants continued until President Musa Yaradua in his administration introduced Amnesty Programme in the year $200925^{\text {th }}$ of June (Ubhenin, 2013). It is important to note that after the amnesty program, kidnapping and hostage taking reduced significantly in the Niger Delta region, however took other dimension in other parts of the country which have continued to be a problem to Nigeria and its government till date.

\section{Causes of Kidnapping}

Some factors have been identified as the causes of kidnapping and hostage taking in Nigeria, most especially the Niger Delta Region. They are as follows: unemployment, politics, poverty, illiteracy, religion, greed and corruption.

Unemployment: Unemployment in Nigeria is alarming, most especially among the youths. According to Balogun, (2010), youth unemployment in Nigeria is a time bomb waiting to explode. This situation has compelled a lot of youths to go into crime such as kidnapping and hostage taking for the purpose of collecting ransom. With the case of Evans; the wealthy kidnapper, a lot of unemployed Nigerian youths have considered kidnapping as a way out of unemployment and poverty. Unemployed youths in the oil Niger Delta Region have their grudges against the government. They believe that they are the oil producing region yet a lot of the youths are not employed. This makes the youths to kidnap foreign expatriates for ransom.

Politics: Politicians in Nigeria are in the habit of kidnapping political opponent for domination and suppression, for example few years ago in Anambra State, the then governor Mr. Ngige was kidnapped and kept hostage for over 24 hour by political gladiators for not complying with their demand. The same is said of Niger Delta region, politicians there also witch hunt their opponent through the instrument of kidnapping. Politicians pay militants groups to kidnap and kill their political opponent. 
Poverty: Nigeria has population of over 197 million people, but about 70 percent of these population are living below the poverty level (Olawale, 2018). Poverty has continued to rise in Nigeria, with almost 100 million people living on less than a $\$ 1$ (£0.63) a day, despite economic growth $(\mathrm{BBC}, 2012)$. The high rate of poverty in Nigeria has made a lot of youths to go into various form of crime most especially kidnapping and hostage taking for ransom. Many kidnappers who got into the police and other law enforcement agency net indicated that the reason they went into kidnapping was because of poverty. The case is not different with Niger Delta region. According to Nigerian Poverty Statistics, the poverty rate in South-South Nigeria is 25.2 percent. Youths in Niger Delta Region form and also join existing militant groups to kidnap foreign oil expatriate and wealthy locals because of poverty. The youths believe that the way out of their poverty is to engage in crime.

Illiteracy: Studies have shown that majority of the people who engage in kidnapping and hostage taking did not have tertiary or higher education. Majority of them have little or no formal education. Education inculcates moral value in the people who chose educational course, but for those, most especially the youths who are illiterate are easily deceived into life of crime. From the foregoing it is worthy to note that illiteracy is a predisposing factor to kidnapping in Niger Delta region of Nigeria.

Corruption: Nigeria is the 148 least corrupt nations out of 175 countries. Put in other words, Nigeria ranked $27^{\text {th }}$ position in corruption index out of the 175 countries of the world. Corruption rank in Nigeria averaged 120.45 from 1996 until 2017, reaching an all time high of 152 in 2005 and a record low of 52 in 1997 (Transparency International, 2017). This is why Nigeria is synonymous with corruption. The present government administration came to power because it promised Nigerians that she would fight corruption, put in other words; zero tolerance for corruption, however since the inception of the administration, it has been observed that the fight against corruption was one sided and a tool to fight opposition party; hence corruption still persist. Nigeria has a culture of corruption and because of this culture of corruption a lot of young people have taken to crime of kidnapping and internet fraud also known as "yahoo yahoo" or "419". Corruption has made it impossible for young people to have their position of endless opportunities in Nigeria; hence they taken to crime, most especially kidnapping and hostage taking.

\section{Psycho-social Impact of Kidnapping on Victims}

The negative psychological effects of being kidnapped are huge, especially for children and women. Depression, anxiety, Post Traumatic Disorder (PTSD) may last a lifetime (Uzochukwu, 2018). Irrespective of the category of kidnapping and the motive for its execution, the psychological and financial impact of the problem can be quite devastating, both for the victims and their relatives. Child sexual abuse as a result of kidnapping also exposes child to the risk of contracting sexually transmitted diseases. Another guised form of sexual molestation of kidnapped children is that the abducted under age victims are often subjected to forced marriage with older husbands (Ibrahim \& Mukhtar, 2017).

Kidnapped victims in Niger Delta region of Nigeria go through a lot of Psycho-social trauma and shock. Physical pains are being inflicted on victims by the abductors in most cases. Victims are depressed and they more often than not develop psychological problem if intervention is not brought to bear quickly. Both the victim and the family of the victim are financially stressed out because of the huge amount of money which runs in millions that are usually demanded by abductors. According to Bailey (2018) traumatic experiences leave an everlasting impact on an individual. Disastrous situations can change an individual, and mold them into a whole new person. A devastating event such as a kidnapping impact on the individual in many ways. The behavior of a kidnapped victim differs greatly before and after the trauma. With the kidnapping there are many obstacles, and after the release there are even more difficulties to be faced. How an individual [victim] handles those effects and challenges all depends on their mind and effort to overcome them. Kidnappings have many effects on victims including: compromising their ability to trust, undermining their ability to feel safe, and causing the suffering they face with Stockholm syndrome.

In a society where the incidence of kidnapping is high, fear limits people's lives and actions. They always move with caution as they do not know who is likely to be the next target. The rich men surround themselves with security guards because of the fear of getting kidnapped (Uzochukwu, 2018). Kidnapping and hostage taking produces a life of fear, people move around about their business with so much fear that they might be kidnapped. This is very devastating because indirectly, the people's freedom is denied them. As a result of fear and psychological trauma, kidnapped victims become less productive in the society (Mbah, 2017). 


\section{Implication for social work intervention with victims of kidnapping and hostage taking}

Social work is a practice-based profession and an academic discipline that encourages social change and development, social stability, and empowerment of the weak and liberation of people. Principles of social justice, human rights, collective responsibility and respect for diversities are basic tenets of social work (International Federation of Social Work [IFSW], 2014). Social worker work with populations with long and short complex histories of abuse and violence combined with pressing physical, mental, emotional, social, and spiritual needs (Kawam\& Martinez, 2016). Psychosocial care is one of the core competencies of social work. There are problems that cannot be solved through orthodox medication and one of such problem is the psychological trauma experience by victims of kidnapping.

There are couple of things social workers can do in practical terms in Niger Delta region of Nigeria to help kidnap victims and significant others of kidnap victims with psychological trauma to recover from psychological trauma and be reintegrated to the family and mainstream of the society after tragic experience of abduction.

* Enhancement of kidnap victim's capabilities: Social workers are saddled with the responsibility of enhancing the capabilities of individuals, family and groups, most especially kidnap victims. They do that through the use of words of encouragement and positive reinforcement. Social workers also use counseling technique to help kidnap victims in the Niger Delta Region to achieve wellbeing. During counseling section, the social worker addresses the pains and hurts in the heart of the kidnap victims. The social worker brings the client to a new reality of living, hope and makes effort to help the client to forget about the traumatic experience of being abducted, tortured and humiliated.

* Social worker links kidnap and hostage taking victims in Niger Delta to resource system: Kidnappers demands ransom from their victims and the ransom run in millions and hundreds of millions. After payment of each ransom kidnap victim and their family are usually and extremely financially exhausted; they have nothing to fall back to. In some cases, the victims and their family borrow or take loans in other to pay ransom. Social workers in their official capacity links kidnap victims to governmental and non-governmental agencies who can provide them with aids.

\$Social workers utilize strength perspective to explore the abilities inherent in kidnap victims: Most often kidnap victims tend to lose everything they have being working for all their life. Some of them feel empty, lacks courage and are depressed; but the social workers use strength perspective which talks about identifying the client's strengths and using those strengths to enhance their wellbeing. Social workers help kidnap victims to explore their inherent abilities and expose them to the possibilities around them and energizes them to get out of mood of depression and become energized and excited about life again.

* Public enlightenment programs: Social workers sensitize the youths on dangers associated with involving in kidnapping and hostage taking; and inculcate into the youths the value of hard work and competency as the root to wealth rather than crime. Scholars have argued that most of the vices that pose cog in the wheel of Nigeria as nation can be solved through value re-orientation. Social workers can help in the campaign for value reorientation to dissuade the young population from engaging in kidnapping as a root to wealth and escape from poverty. On the other hand, social workers engage in public enlightenment sensitization to educate the populace on the need to always be security conscious; sensitive and being alert at all times; being at the right place at the right time and not keeping late night to meetings. This is because most kidnappers take advantage of security carelessness of their victims to abduct them.

Advocacy: Social workers can advocate for welfare program for kidnapped victims in the Niger Delta region of Nigeria. Social workers can lobby the government to appropriate budget to take care of authenticated victims of kidnapping. As a result of this welfare program the psychological effect of being kidnapped will be reduced or ameliorated.

\section{Conclusion}

Kidnapping and hostage taking have taken alarming dimension over the years across Nigeria and most especially the Niger Delta region of Nigeria. Despite the amnesty program, kidnapping and hostage taking have persisted taking different kinds of shapes and form. It was discovered that the emergence of militancy or insurgent groups who kidnap foreign expatriates and wealthy locals perpetuated the acts initially as a result of perceived injustice in distribution of oil proceeds from the region by the government. The study showed unemployment, poverty, political strife, illiteracy and corruption were the major causes of kidnapping and hostage taking in Nigeria and Niger Delta region in particular.

98 
The study shows that kidnapping and hostage taking have psychological traumatic impact on the victims. Social workers have significant to play in effort to help kidnap victims to recover and achieve wellbeing.

\section{Recommendation}

To achieve maximum security of life of citizen of Nigeria and that of the populace of Niger Delta Region in particular and also to ensure psychosocial wellbeing of kidnapped victims; the study recommended the following:

The federal government should employ and empower social workers in the Niger Delta region; to enable them to be poised to render services to kidnap victims.

* Social workers should adopt collaborative approach to involve other professionals like doctors, nurses, and psychologist. They also have to utilize inter agency model involving government and non-governmental organization to be able to meet the needs of kidnap victims in the Niger Delta region of Nigeria.

* The government should invoke and implement the establishment of social work unit in every health or hospital facility across the country and Niger Delta region in particular.

* Value re-orientation programs should be put in place in all the institution of learning and work place to dissuade the youths from engaging in kidnapping.

* The government should in consultation with social workers establish effective welfare program which will ensure the psychological recovery and re-integration of kidnap victims into the main stream of the society and the family in particular.

\# The government should enact policy and action plans which will ensure stringent punishment for kidnap and hostage taking perpetrators across Nigeria and Niger Delta region in particular.

\section{References}

Abdulkabir, O. S. (2017). Causes and incisive solutions to the widespread of kidnapping in Nigeria. Retrieved from https://www.omicsonline.org/open-access/causes-and-incisive-solutions-to-the-widespread-ofkidnapping-in-nigeriacurrent-administration-under-scholastic-scrutiny-2332-07611000258.php?aid=89992.

Amachree, D. (2017). The evolution of kidnapping in Nigeria. Retrieved from: http://bulwarkin telligence.com/reports/security-threats/evolution-kidnapping-nigeria/

Azgaku, C. B. (2014). Kidnapping in the Niger-Delta Region of Nigeria: Issues and Challenges .International Journal of Research Development, 1(1), 1-9. Retrieved from http:// www .globalacademicgroup.com/journals/approaches/Kidnapping\%20in\%20the\%20Niger.pdf.

Bailey, E. (2018). Effects of kidnappings. Retrieved from https://elainabailey.weebly. com/kid nappingessay.html.

BBC (2012). Nigerians living in poverty rise to nearly 61\%. Retrieved from https://www .bbc.com/news/world-africa-17015873.

Boihtlung, M. (2017). Social work intervention. Retrieved from http://www.academia. edu/ 9182992/Social_Work_Intervention.

Francis, P., LaPin, D. \&Rossiasco, P. (2011). Securing development and peace in the Niger Delta: A social and conflict analysis for change. Retrieved from https://www.wilsoncenter. org/sites/default/files/AFR_110929_Niger\%20 Delta_0113.pdf.

GCF (2017). Algiers memorandum on good practices on preventing and denying the benefits of kidnapping for ransom by terrorists.https://www. thegctf.org/ documents /10162/159 874/ Algiers+MemorandumEnglish.pdf.

Hogan, C. M. (2013). Niger river in M. McGinley (ed.), Encyclopedia of Earth, Washington, DC: National Council for Science and Environment.

Ibrahim, B. \& Mukhtar, J. I. (2017). An analysis of the causes and consequences of kidnapping in Nigeria. An international multi-disciplinary journal,11(4), 134-143 Retrieved from

https://www.researchgate.net/publication/321798892_An_Analysis_of_the_Causes_and_Consequences_o f_Kidnapping_in_Nigeria.

IFSW (2014). Global definition of social work. Retrieved from https://www.ifsw.org/what-is-social-work/globaldefinition-of-social-work/. 
Kawam, E.\& Martinez M. J. (2016). What every new social worker needs to know: Trauma informed care in social work. Retrieved from http://www.socialworker.com/feature-articles/practice/trauma-informed-carein-social-work/.

Mbah, C. (2017). The cause and effects of kidnapping in Nigeria. Retrieved from https:// infoguidenigeria.com/causes-effects-kidnapping-nigeria/.

Moorhouse, A. (2018). Kidnap, ransom and a travelling workforce. Retrieved from http://dynamiqglobal.com/cms_uploads/docs/dynamiq_kidnap,-ransom-and-a-travelling-workforce_keyconsiderations.pdf.

Okeowo, A. (2013). A kidnapped family and terrorists in West Africa. Retrieved from https://www.newyorker.com/news/news-desk/a-kidnapped-family-and-terrorists-in-west-africa.

Olawale, S. (2018). Nigeria poverty statistics and poverty rate in Nigeria. Retrieved from https://naijaquest.com/nigeria-poverty-statistics/.

Ploch, L., Blanchard, C. M., O'Rourke, R., Mason, R. C. \& King, R. O. (2011). Piracy off the horn of Africa. Retrieved from http://www.dtic.mil/docs /citations/ ADA543786.

SDN (2018). The Niger Delta. Retrieved from https://www.stakeholderdemocracy.org/about-the-niger-delta/.

Transparency International (2017). Nigeria corruption rank 1996-2018. Retrieved from https://tradingeconomics.com/nigeria/corruption-rank.

Ubhenin, O. E. (2013).The federal government's amnesty programme in the Niger-Delta: An Appraisal. YönetimBilimleriDergisi, 11(21), 179-203. Retrieved from http://dergipark.gov. tr/download/article-file/46280.

Uzochukwu, M. (2018). Kidnapping: overview, causes, effects, and solutions. Retrieved from https://owlcation.com/social-sciences/Kidnapping-Overview-Causes-Effects-and-Solutions.

Walther, O. \&Retaille, D. (2011). Sahara or Sahel? The fuzzy geography of terrorism in West Africa. Retrieved from https://papers.ssrn.com/sol3/papers.cfm?abstract_id=1803996.

Yun, M. (2008). Hostage Taking and Kidnapping in Terrorism: Predicting the fate of a hostage. Retrieved from https://www.tandfonline.com/doi/abs/10.1080/10576100802206566. 